\title{
Közösségi kvízjátékosok Magyarországon
}

\section{Public quizzing players in Hungary}

\section{ÖSSZEFOGLALÓ}

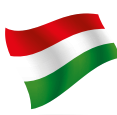

A közösségben játszott kvízjáté-

kok hazánkban és más országokban is rendkívül népszerűvé váltak az utóbbi években; itthon rövid idő alatt több ezer résztvevőt sikerült bevonni a szervezett kikapcsolódásba. A 2017 júliusában végzett kérdőíves felmérés arra volt kíváncsi, hogy elsôsorban kik választják ezt a szabadidős tevékenységet, nekik milyen rekreációs

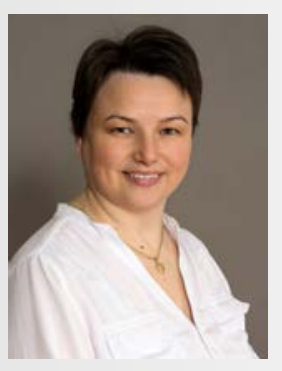

Szerző:

Bukta Zsuzsanna

PhD, egyetemi adjunktus Munkahelye: ELTE Egészségfejlesztési és Sporttudományi Intézet Levelezési címe: 1117 Budapest, Bogdánfy u. 10. E-mail címe: bukta. zsuzsanna@ppk.elte.hu Tudományos tevékenysége: egyetemi oktató Kutatási területek: sportegyesületek, egyéb nonprofit szervezetek, önkormányzati sportfinanszírozás fotó: Hámori Zsófia

\section{BEVEZETÉS}

Hazánkban az utóbbi 4-5 évben jelentősen megnövekedett a közösségben, csapatban játszott szellemi vetélkedők népszerúsége. Míg korábban csak kisebb klubokban vagy magánszervezésben zajlottak a játékok, nagyjából 2009 óta elterjedtek az ún. kocsmakvízek, melyek ma már rendszeresen akár több ezer résztvevőt is aktivizálnak. A Quiznight rendezvénysorozat 2009-től, a Pub's Culture jelen formájában 2013 óta tartja rendezvényeit. Mindkét kezdeményezés képviselői szerint a kereslet folyamatosan bővül, egyre több csapat csatlakozik a rendezvényekhez, folyamatosan jelentkeznek a kvízmesterek, divatosak lettek a csapatépíto, egyéni igények alapján összeállított kvízestek.

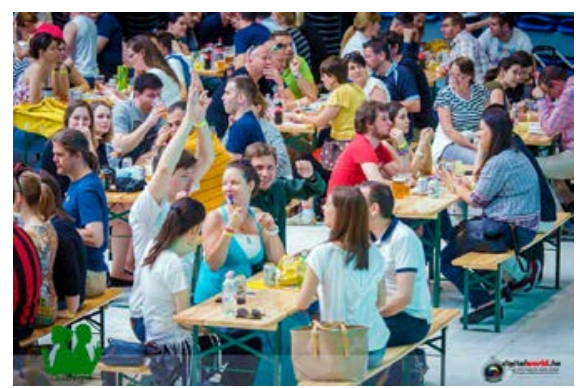

A Quiznight 2016/17-es idényének döntője a budapesti Tüske csarnokban. Quiznight Hungary Final of the 2016/17 season in Budapest. Forrása: digitalworld.hu

A rendszeresen, illetve alkalomszerúen játszók száma 4-5 ezerre becsülhetô, ez a szám meghaladja a legtöbb egyéni sportágban igazolt versenyzők számát, így komoly szabadidős tényező, amelynek szabadidős sportbajnokságokhoz hasonló versenyrendszere van.

A kocsmában játszott kvíznek komoly múltja van Nagy-Britanniában, de sok más európai és Európán kívüli ország felé is egyre inkább terjed, hazánkba is külföldi minta alapján került. A közösségi kvízjáték a hazai rekreációs szakirodalomban még nem önálló kategória. A szellemi rekreáció témakörében, Fritz (2015) a társaságiegyéni rekreációs tevékenységek közt említi, Magyar (2014) a játékokat aktivitás alapján osztályozva a szellemi játékok között az „egyéb memóriafejlesztő és szellemi játékok" kategóriájában nevesíti a kvízt. Nehezíti a kategorizálást, hogy a szellemi kvízjáték egyénileg, csoportosan, írásban, szóban, társasjáték formájában vagy az interneten is úzhető. A kvízezés akár még arra a tevékenységre is érthető, amikor a televíziós vetélkedők nézése közben a család vetélkedik azon, ki találja ki hamarabb a megfejtést; illetve a nézők bevonásának az a formája, amikor virtuális felületeken keresztül maguk is bekapcsolódhatnak a játékba (Azurmendi et al. 2015.). Rokon tevékenység a keresztrejtvényfejtés, számtalan változatban; többek között azt is játsszák csoportos bajnokságok formájában, illetve a különböző társasjátékok bajnokságai, amelyeket elsősorban rajongók szerveznek az interneten.

A fentiek alapján tehát a több ezer résztvevoót vonzó kvízjátékok a szereplők számára jelentős szabadidő-eltöltési tényezővé váltak. Hazánkban legutóbb 2009/10ben készült időmérleg-kutatás (KSH, 2012), amely szerint a szabadidő társas eltöltésére naponta átlagosan 48 percet fordítunk. Ez a mutató a 23 évvel korábbi értékekhez képest - ha nem is olyan jelentôsen, mint az olvasás - csökkent (KSH, 2013). A szabadidő eltöltésének legnagyobb hányadát minden korosztályban a televíziózás és internetezés tölti ki, s feltehetőleg a következő időmérleg-kutatások e tekintetben még rosszabb helyzetről fognak beszámolni. A szabadidő eltöltésén belül a kvízjáték valószínúleg a „társas szórakozás" kategóriájába sorolható, amelyre napi 5 perc jut átlagosan; a 20-29 éves korosztályba tartozó budapesti férfinak 12, a 30-39 éves korcsoportú budapesti nőnek csak 4 perce jut ilyen elfoglaltságra egy nap. A szabadidő társas eltöltésére vonatkozó összehasonlító (1986/87, 1999/2000) adatok szerint a nők kezdenek felzárkózni a férfiakhoz (KSH, 2012).

\section{MÓDSZEREK}

A 2017 júliusában felvett nem reprezentatív kérdőíves felmérésben összesen 227-en vettek önkéntesen részt. A 33 kérdéses online kérdőívet Google Ürlapok segítségével állítottuk össze, s célzottan a közösségi kvízek - elsősorban Facebookos - internetes oldalain kértünk megosztást, olyan felületeken, ahol a játékosok egyébként is hozzájutnak információhoz. A kérdőív három fô területe: a játékosok alapvető tulajdonságai, életkörülményei; a szabadidős és rekreációs szokásaik, valamint a kvízjátékkal kapcsolatos motivációik.

\section{EREDMÉNYEK}

\section{A hazai kvízjátékos profilja}

A kérdőívet kitöltők nemek szerinti megoszlása teljes egyenlőséget mutatott, 50-50\%-os volt az arány. Életkor tekintetében a fiatal és az aktív korosztály dominál, 
a válaszadók 80\%-a 18-49 év közötti, bár a 30 év felettiek ezen belül jelentősen többen vannak. Nem meglepő módon a kvízjátékosok döntő többsége Budapesten él, elenyésző a városnál kisebb településen, illetve külföldön élők száma. Bár a kitöltők között több a házastársi vagy élettársi viszonyban élők száma, közel 86\%-uknak nincs eltartandó gyermeke, amely természetesen szoros összefüggésben áll a rendelkezésre álló szabadidô mennyiségével is.

A magyar kvízjátékos leginkább munkavállaló, a kitöltők között alig akadt diák, havi jövedelem szempontjából pedig a játékosok között nincs domináns csoport. A válaszadók több mint fele nem úzött sosem olyan foglalkozást, amelyben lexikális vagy logikai tudását fejlesztette volna, ebből a szempontból az sem meglepő, hogy a válaszadóknak csak egyötöde használ fel valamit a kvízjáték során tanultakból és tapasztaltakból munkája során: nagyon sokan említették, hogy az iskolában a számonkérés vagy a tanulás játékos formája a kvíz, munkahelyi csapatépítőkön használt játék. A nemzetközi szakirodalom számos cikket közöl a kvízjátékok oktatásban, nevelésben való hasznosításáról, feltehetôleg a hazai pedagógusokat is inspirálja a kvízjátékok elterjedése és az azon való részvétel.

\section{A hazai kvízjátékosok szabadidös szo-} kásai és motivációi

A kvízjátékosok többsége saját bevallása szerint több szabadidővel rendelkezik, mint ami az idómérleg-kutatások által megadott érték. A heti rendszerességgel űzhetô kvízjátékok gyakorlatilag az egy napra eső szabadon felhasználható időt foglalják el egy játékos idejéből. A válaszadók 60\%-a legalább heti egyszer játszik, feltehetőleg a bajnokságok idején, az ünnepek, nyári szünet idôszaka kivétel. A nyilvános kvíz mellett családdal, barátokkal, magánszervezésben is sokan játszanak, amely a közösségi kvízek továbbgyúrúző, kedvező „mellékhatásának” tekinthetők. A kvízesek nagy részéról egyébként is elmondható, hogy barátokkal vagy kollégákkal játszik elsősorban, bár a válaszadók közel fele a kvízek során megismert játékostársakat is említi. Ez erősíti a kvízes aktivitás szociális funkcióját. Többen említették, hogy a rendszeres heti kvízjáték „megoldja” a baráti kör szervezett összegyűlését, s a motivációk között is előkelő helyen áll a játék általi közösségi élmény megélése.
A kvízjátékosok a szabadidejüket változatosan és igényesen töltik. Sokan soha vagy csak ritkán televízióznak, a válaszadók mindössze negyede játszik számítógépes játékokat gyakrabban, mint havonta. Kedvelt időtöltés a keresztrejtvényfejtés, társasjátékozás, filmnézés és a színház-, illetve koncertlátogatás. A szellemi sportok más válfajait (sakk, dáma stb.) kevesen üzik, a kártyajátékok sem annyira kedveltek a kvízesek körében. Szinte egyáltalán nem jellemző a modellezés, makettépítés, illetve az egyéb múvészeti jellegú szabadidős foglalkozás; az egyre népszerúbbé váló logikai szituációs játékokat, szabadulószobákat viszont már a válaszadók 60\%-a kipróbálta vagy rendszeresen látogatja.

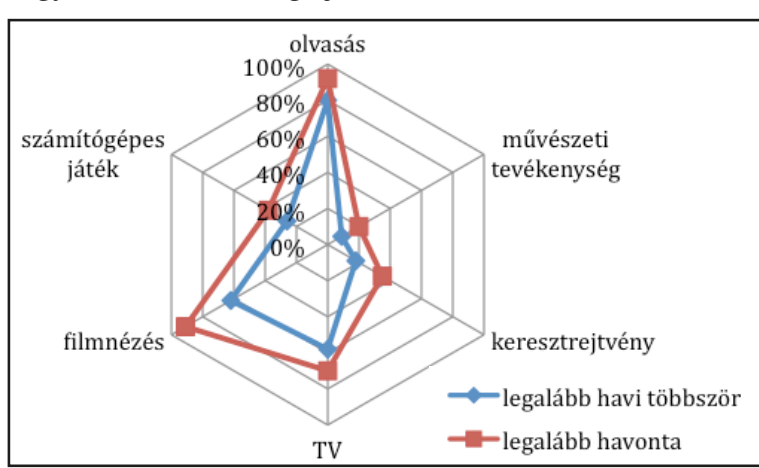

Jellemzően otthoni szabadidős tevékenységek űzésének gyakorisága a magyar kvízjátékosok körében Hungarian Quizzing players' home recreation activities Forrása: saját feldolgozás 2017 / Own survey 2017

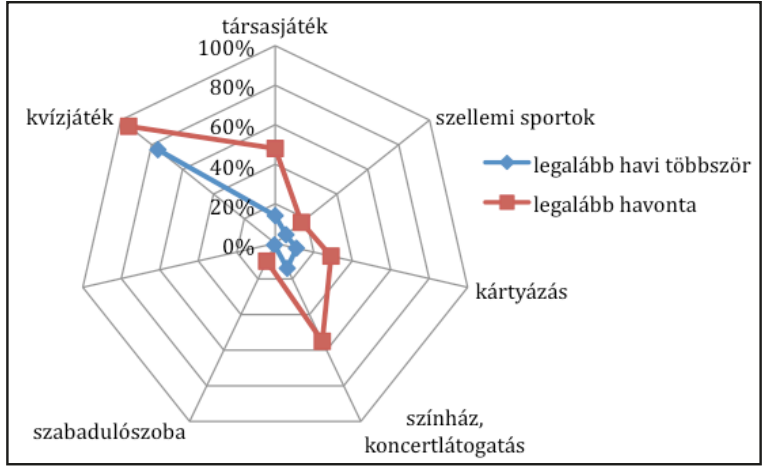

Jellemzően társas szabadidős tevékenységek űzésének gyakorisága a magyar kvízjátékosok körében

Hungarian Quizzing players' public recreation activities Forrása: saját feldolgozás 2017 / Own survey 2017

A kvízesek a legnépszerúbb szabadidősportok valamelyikét legalább alkalmanként űzik, elenyésző azok száma, akik semmilyen sporttevékenységet nem jelöltek be. A sportágak népszerúsége teljes mértékben megegyezik a szabadidősportos felmérésekben legkedveltebbnek bizonyuló futás, kerékpározás, gyaloglás, túrázás, úszás, focizás tevékenységekkel. A válasz- adók kétharmada követi a sporteseményeket passzív befogadóként is.

A szabadidő-fogyasztás típusát tekintve a kvízjátékosok a rekreációnak inkább az aktív, résztvevő típusába tartoznak, nem véletlen, hogy a kvíz kedvéért társaságba járnak és nemcsak az interneten elérhető játékokat választják. A kvízhez hasonló aktivitással végzett tevékenységek között szinte mindenki aktív, cselekvéses rekreációs formát említett. Az érdeklődés mélységét tekintve sokkal többen vallják magukat szenvedélyes, egy szabadidős szokást intenzíven gyakorló embernek, mint kíváncsiskodó, mindenbe belekóstoló típusnak. Ennek alapján a Fritz (2015, 21-22. o.) által bemutatott fogyasztói típusokból a kvízesek inkább inspiratív, mint akkumulatív szabadidő-fogyasztók.

A motivációs tényezók vizsgálati eredményei: a kitöltők leginkább a kikapcsolódást, a napi rutintól való elszakadást szeretik a közösségi kvízeken; emellett a tudás gyarapítása, új dolgok megismerése és a közösségi élmény dominál. Fontos számukra a játékban rejlő kihívás és a megoldások okozta sikerélmény, ám kevésbé érdekli ôket a versengés; a nyeremény lehetôsége vagy a szereplési vágy kiélése.

\section{KÖVETKEZTETÉSEK}

A közösségi kvízjátékosok egy jól körülhatárolható réteghez tartoznak, ezen belül azonban nagy számban mozgósíthatók. Örömteli, hogy nagyon sokan játszanak az átlagosan kevés szabadidővel rendelkezó 30-49 éves korosztályból, bár közülük sokan családalapítás előtt, vagy a gyermekek felnevelése után állnak. A kvízjátékok a bulizásból kiöregedett korosztálynak nyújtanak élvezetes közösségi élményt, gyakran a tevékenység átgyưrúzik a munka vagy a magánélet területére is, általában kedvező hatással. Összességében a szervezett kvízjátékok önálló kezdeményezésként való elterjedése sok pozitív társadalmi hatással bír.

\section{IRODALOMJEGYZÉK}

Azurmendi, A. - Llorens, C. - López Vidales, N. - Bas Portero, J.J. (2015): Audience participation as added value for public service proximity television. The case study of ETB 2's La noche de...". Revista Latina de Comunicación Social. 70. 490-518. DOI: 10.4185/RLCS-2015-1056en

Központi Statisztikai Hivatal (2012) Idómérleg 2009/2010 Összefoglaló Adattár. KSH, Budapest. From: http://www.ksh.hu/docs/hun/xftp/idoszaki/ idomerleg/idomerleg0910.pdf
Fritz, P. (szerk, 2015): Szellemi rekreáció. Dialóg Campus, Budapest-Pécs Központ Statisztikai Hivatal (2013) Kulturálódási szokásaink. A lakosság televíziózási, olvasási jellemzőinek vizsgálata az időmérleg-felvételek segítségével. KSH, Budapest. https://www.ksh.hu/docs/hun/xftp/idoszaki/pdf/ kult_szokasok.pdf

Magyar, M. (2014. szerk.) Játéktár (Játékelmélet és módszertan, Kiegészító rekreációs programok) 2013/14 tanév OKJ animátor óravázlatai szerkesztve. Szinergia Szakképző Iskola Óbudai Tagintézménye, Budapest 